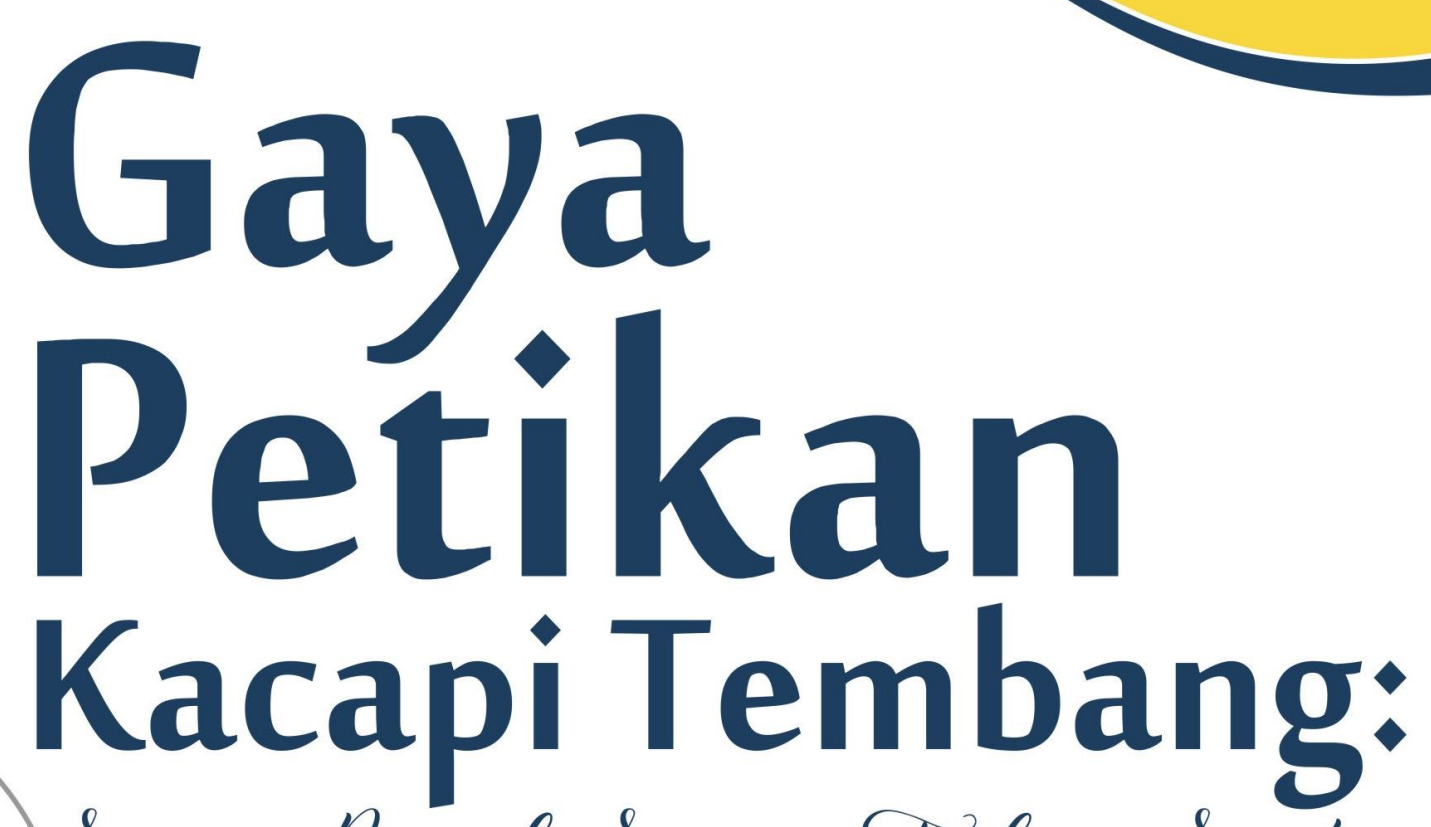

Pequtar Biografi Seniman Tambang Sunda

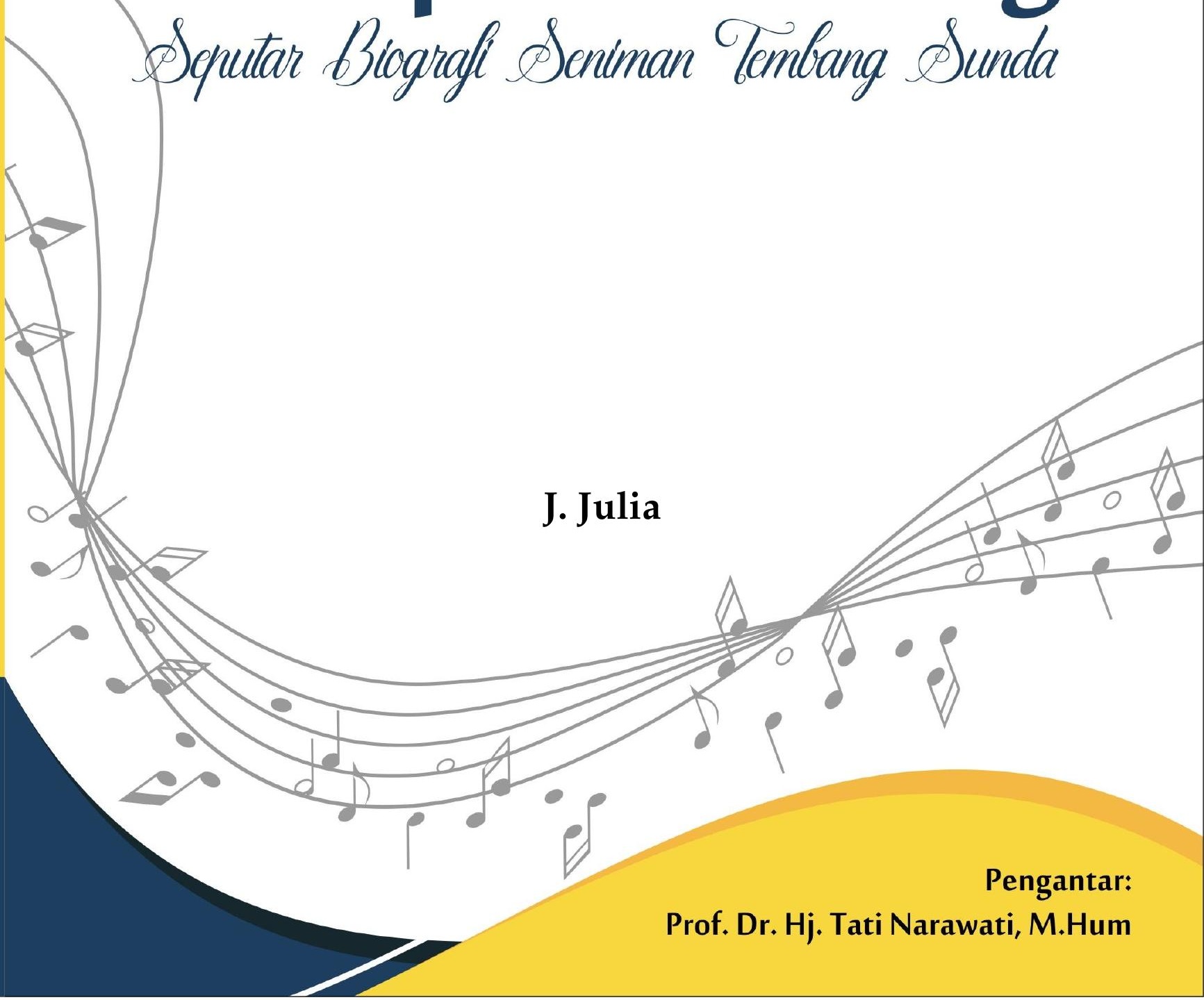




\section{Gaya Petikan Kacapi Tembang: Seputar Biografi Seniman Tembang Sunda}

Dr. Julia, S.Pd., M.Pd

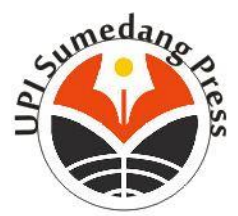

UPI Sumedang Press 


\section{Gaya Petikan Kacapi Tembang: Seputar Biografi Seniman Tembang Sunda}

Penulis:

Dr. Julia, S.Pd., M.Pd

Editor:

Dr. Prana Dwija Iswara, M.Pd

Tata Letak:

Ariana, S.Kom

Sampul:

Bayu Sundawa, S.Pd

Penerbit Edisi Kesatu:

Prodi Pendidikan Seni Sekolah Pascasarjana UPI

Bekerja sama dengan CV. Bintang WarliArtika

Penerbit Edisi Kedua:

UPI Sumedang Press

Jl. Mayor Abdurachman No. 211 Sumedang

Jawa Barat 45322

Email: upismd.press@upi.edu

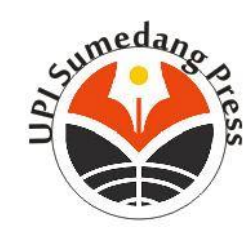

ISBN 978-602-8617-26-0

ISBN 978-602-6438-16-4

$217 \mathrm{hlm} ; 17$ × $25 \mathrm{~cm}$

Cetakan Kesatu, Agustus 2011

Cetakan Kedua, Februari 2018

(C) 2018

Hak cipta pada penulis dilindungi oleh undang-undang.

Dilarang memperbanyak sebagian atau seluruh isi buku ini tanpa izin tertulis dari penulis dan penerbit. 
Oh Musik,

dalam kedalamanmu kami meletakkan hati

dan jiwa kami; Engkau mengajarkan kepada

kami untuk melihat dengan telinga kami

dan mendengar dengan hati kami.

- Khalil Gibran

Buku ini dipersembahkan untuk

Gan-Gan Garmana dan Ruk-Ruk Rukmana

sebagai guru yang menjadi nakhoda

dalam berlayar mengarungi jagat tembang Sunda 


\section{Pengantar}

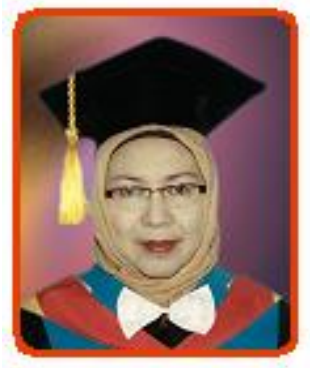

Buku yang hadir di hadapan pembaca ini, berasal dari tesis sdr. Julia pada Prodi Pendidikan Seni UPI yang meneliti gaya pirigan dua orang seniman dalam memetik kacapi indung dalam mengiringi tembang Sunda Cinjuran. Tembang Sunda Cianjuran seperti yang kita kenal adalah musik vokal yang diiringi instrumen kecapi (kecapi indung dan kecapi rincik) serta suling. Konon seni yang khas ini lahir pada akhir abad XVIII pada masa Bupati Dalem Enoh. Namun baru mengalami puncaknya pada masa Dalem R.A. Prawiradiredja I (1813-1833). Dalam perkembangan selanjutnya Tembang Sunda Cianjuran dipengaruhi oleh degung, pupuh, tembang, beluk, kakawen, dalang dan kawih. Maka kini, tak mengherankan apabila muncul beberapa gaya tembang Cianjuran atau lebih dikenal dengan istilah wanda yaitu: papantunan, jejemplangan, dedegungan, rarancagan, dan kakawen.

Kemunculan wanda dalam tembang Sunda Cianjuran bagaikan penanda historis yang melekat pada masyarakat Sunda, karena bagaimanapun juga seni adalah produk budaya yang menyimpan nilai etik dan estetik yang diacu oleh masyarakat pendukungnya. Kehadiran seni di masyarakat tidak luput dari pengaruh berbagai aspek kehidupan, bahkan keberadaannya dari waktu ke waktu direfleksikan secara berbeda-beda oleh masyarakatnya. Untuk memahami dan mengungkapkan hal tersebut diperlukan kajian yang mendalam. Apabila merunut kelahirannya serta siapa yang menjadi penikmatnya, maka seni tembang Sunda Cianjuran memiliki kategori sebagai seni adiluhung atau art for the cultural elite (Hauser, 1982:556). Alasan Hauser, bahwa seorang seniman mencipta bukan hanya untuk kemanusiaan saja, tetapi seniman mencipta untuk sebagian tertentu dari kelompok masyarakat atau sekelompok lapisan masyarakat tertentu. Gaya ciptaan seniman bukan saja ditentukan oleh perkembangan kemampuan senimannya, tetapi juga ditentukan oleh strata kultural yang khas dari masyarakatnya. Peran dan keterlibatan unsur-unsur masyarakat dalam peristiwa seni adalah sangat penting dan perlu diperhatikan secara khusus karena seluruh lapisan masyarakat dan unsur dalam masyarakat selalu ikut mendukung keberadaannya. Dengan demikian, seni itu diciptakan, dilakonkan, dipertahankan dan dikembangkan oleh masyarakatnya sendiri.

Seorang seniman dalam masyarakat bukanlah individu dengan identitas istimewa, tetapi manusia biasa yang memiliki bakat-bakat kecerdasan istimewa yang bisa mengambang dengan bebas tak terikat oleh lapisan masyarakatnya (Hauser,1982:548). Akan tetapi produknya yang hanya bisa dinikmati oleh lapisan masyarakat tertentu yang memberikan identitas tertuju pada masyarakatnya. Apabila Hauser mengkategorikan produk seni berdasarkan pada siapa yang menjadi penikmatnya, maka Becker (1982) mengkategorikan seniman berdasarkan pada produknya. Seniman professional/integrated artist, adalah seniman yang bisa mengantisipasi perubahan zaman. Seniman dikategorikan maverick apabila karyanya tidak terpengaruh oleh perubahan zaman. Folk artist, adalah seniman desa. Adapun naive artist adalah orang yang bukan seniman tetapi berperilaku sebagai seniman. 
Produk seni yang dihasilkan oleh individu/masyarakat mengalami perubahan dan perkembangan sesuai dengan dinamika yang terjadi dalam masyarakat tersebut. Di sisi lain produk seni yang dihasilkan oleh masyarakat juga difungsikan sebagai ekspresi sentimen secara kolektif untuk melindunginya dari pengaruh yang merugikan masyarakat tersebut. Proses inilah yang disebut proses mempertahankan integritas sekaligus sebagai bentuk solidaritas keperluan kelompok. Fungsi proses ini adalah untuk menunjukkan identitas kelompok agar berbeda dari kelompok lain. Jadi, integritas kelompok menghasilkan identitas kelompok.

Identitas yang dihasilkan itu diwujudkan dengan suatu produksi, bukan esensi yang tetap menetap. Akibatnya, adalah identitas selalu berproses, selalu membentuk, di dalam bukan di luar sebagai suatu representasi. Ini juga berarti otoritas dan keaslian identitas dalam konsep 'identitas kultural'. Identitas hanya bisa ditandai dalam perbedaan sebagai suatu bentuk reprentasi dalam sistem simbolik maupun sosial, untuk melihat diri sendiri tidak seperti yang lain. Perbedaan identitas individu ditentukan oleh tingkatan yang berhubungan dengan individu yang lain dalam kelompok identitas yang sama. Identitas bersifat ambigu. Keambiguannya itu berhubungan dengan sejarah dan muatan kultural yang dapat dinegosiasikan (Redfield dalam Irwan Abdullah, 2007:14).

Dinamika perubahan yang terjadi dalam jagat tembang Sunda Cianjuran, tidak lepas dari penyesuaian identitas guna pengokohan dirinya dalam suatu perputaran dunia dan budaya yang selalu berkembang. Sebagai sebuah produk masa lampau, kehadiran tembang Sunda Cianjuran di masa kini membuktikan fleksibilitas budaya Sunda yang bisa ngigelan zaman, artinya kreatif dan inovatif dalam menghadapi tantangan zaman. Kreativitas dua orang pamirig kacapi indung yang bernama Ruk-Ruk Rukmana dan GanGan Garmana membuktikan bahwa tradisi tidak pernah bisa mati, tetapi dengan lentur mengalami pengayaan dan penyesuaian budaya. Walaupun dari akar budaya yang sama arah pengembangan kedua orang itu berbeda. Namun demikian, Penguatan tradisi atau pengembangan tradisi, tampaknya dua hal yang sangat penting dilakukan dalam upaya merangkul beragam lapisan masyarakat di Kota Bandung ini. Di sisi kualitas pakem tembang Sunda Cianjuran tetap dipertahankan di sisi lain secara kuantitas, teknologi informasi dimanfaatkan sebagai media penyebaran dan transmisi nilai budaya Sunda ke tengah masyarakat urban.

Terkait dengan hal tersebut, kebudayaan didefinisikan oleh Geertz sebagai pola dari pengertian-pengertian atau makna-makna yang terjalin secara menyeluruh dalam simbol-simbol dan ditransmisikan secara historis (Clifford Geertz, 1992:1-2). Budaya tembang Sunda yang terekam dalam vokal penembangnya, dalam nada lagunya, dalam syairnya, dalam pirigan/iringan kecapinya, dalam tata cara melakukannya, bahkan dalam busana/rias para pemainnya semuanya menjalin makna yang mengacu pada simbol budaya kaum menak Sunda. Dalam konteks tembang Sunda Cianjuran, tarik menarik kultural masyarakat Sunda pada abad 18-an dan abad 21 saat ini, perubahan adalah suatu kewajaran. Tidak ada yang tidak berubah karena perubahan adalah keabadian. Namun demikian, dibalik semua perubahan tanda-tanda kultural yang paling kecilpun tak dapat menyembunyikan bahwa tembang Sunda Cianjuran adalah sebuah produk masyarakat Sunda yang menyimpan nilai etika dan estetika yang sangat tinggi. Pengakuan terhadap 
nilai kebudayaan Sunda tersebut dibuktikan dengan rekomendasi Unesco bahwa budaya Sunda adalah the most exelent cultural humanist.

Sekian, selamat membaca.

Bandung, akhir tahun 2010

Prof. Dr. Hj. Tati Narawati, M.Hum 


\section{Prakata}

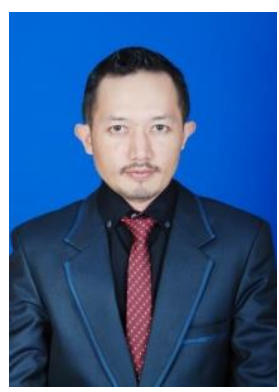

Pada tahun 2008, hasil penelitian ini berhasil disidangkan di Prodi Pendidikan Seni Sekolah Pascasarjana Universitas Pendidikan Indonesia. Saat itu, ketua Program Studi Pendidikan Seni, Prof. Dr. Hj. Tati Narawati, M.Hum sebagai salah seorang penguji, dan Prof. Dr. Waridi, M.Hum (alm) yang merupakan salah seorang pembimbing tesis, menyarankan kepada saya untuk menyajikan hasil penelitian ini ke dalam bentuk buku. Saya pun tertarik dengan rujukan tersebut. Namun sayangnya, setelah melakukan pengajuan ke beberapa penerbit, tidak ada satupun dari penerbit yang menerima usulan hasil penelitian ini untuk diterbitkan. Alasan yang muncul saat itu adalah bahwa topik yang disajikan kurang populer sehingga dikhawatirkan tidak dapat mengembalikan modal produksi. Dengan kata lain, secara komersil hasil penelitian ini diprediksi kurang memiliki daya jual sehingga dapat merugikan pihak penerbit.

Saat itu pula saya menyadari dan sekaligus gering nangtung ngalanglayung, betapa tulisan-tulisan yang berkaitan dengan seni dan budaya kurang mendapatkan tempat dihati para penerbit, khususnya seni budaya lokal seperti yang saya tulis. Akhirnya, saya mengurungkan niat untuk membukukan hasil penelitian ini, sambil membayangkan bahwa tulisan ini hanya akan menjadi arsip yang tersimpan rapi di lemari-lemari yang tidak pernah mendapatkan sentuhan dan perhatian, dan tidak akan jelas apa manfaatnya baik bagi kalangan akademisi maupun kalangan masyarakat luas khususnya para seniman dan budayawan.

Beberapa bulan berlalu, ada beberapa kalangan yang menanyakan dan memerlukan hasil penelitian ini, untuk dijadikan sebagai bahan rujukan dalam penelitian terutama yang berkaitan dengan persoalan tembang Sunda dan penelitian yang berbentuk biografi. Tidak lama berselang, sekalangan mahasiswa S1 dan S2 yang sedang melakukan penelitian berdalih kesulitan untuk mendapatkan buku referensi ihwal kacapi dalam tembang Sunda Cianjuran, sehingga meminta file tulisan ini untuk dijadikan sebagai salah satu bahan acuan. Berdasarkan fakta-fakta tersebut, hati saya tergugah kembali untuk mempublikasikan hasil penelitian ini dengan berbagai upaya yang dapat saya lakukan, meskipun saya menyadari bahwa tulisan ini bukanlah tulisan populer. Fakta-fakta seperti disebut di atas, antara lain mengenai kurangnya sumber-sumber referensi ihwal dunia tembang Sunda, memang masih menjadi persoalan yang belum terpecahkan sampai sekarang. Hal ini membuktikan bahwa budaya literasi masyarakat masih rendah, terutama para praktisi seni yang kebanyakan masih asyik dengan budaya ucap-dengarnya. Oleh karena itu, didasari niat tulus untuk ikut menyumbang sumber referensi kepada jagat tembang Sunda, saya mengharapkan tulisan ini dapat bermanfaat khususnya bagi kalangan-kalangan yang giat melakukan penelitian dan haus akan sumber bacaan, dan umumnya bagi masyarakat luas terutama kalangan seniman tembang Sunda yang berminat untuk ikut mengembangkan budaya literasi dan menyumbangkan pikiran melalui lisan dan tulisan.

Melalui buku ini, saya mengajak para pembaca untuk berkelana ke dalam jagat tembang Sunda khususnya pada ranah musik Cianjuran. Dua gaya petikan kacapi indung 
para ahli Cianjuran yang menjadi acuan bagi banyak kalangan seniman kacapi, menjadi fokus utama dalam pembahasan buku ini. Karenanya, dua jenis petikan kacapi berikut perkembangannya menjadi sasaran pembicaraan, sebagaimana terjadi pula dalam kehidupan realnya dalam dunia tembang Sunda Cianjuran yang selalu hangat diulas sampai saat ini. Bahkan, persoalan sosial yang kerap terjadi dalam dunia Cianjuran terutama di kalangan seniman kacapi ikut mewarnai alur cerita dalam buku ini. Lebih tepatnya, buku ini menyajikan biografi singkat dari dua orang seniman kacapi yang memiliki virtuositas luarbiasa dalam bidang yang digelutinya, sehingga menjelma menjadi sosok yang disegani dan digandrungi serta patut untuk digugu dan ditiru dalam bidang keilmuannya.

Pada edisi kedua ini, ada beberapa perubahan yang dilakukan, yaitu isi buku disajikan sebagaimana versi aslinya dari penelitian tesis saya, sehingga pembaca dapat lebih memahami kajian dalam buku ini secara lebih komprehensif, yaitu apa permasalahannya, teori apa yang digunakan, metode yang digunakan, dan temuan-temuan serta pembahasannya. Dengan demikian, diharapkan karakteristik khusus dari penelitian ini dapat menjadi ciri khas tersendiri dalam penelitian di bidang seni.

Buku ini dapat dipublikasikan karena dilibati oleh berbagai pihak yang memiliki partisipasi sangat tinggi diiringi niat tulus untuk mengembangkan seni dan budaya bukan hanya dari segi lisan dan tulisan, tapi juga melalui pengorbanan waktu, tenaga, pikiran, dan kajembaran. Oleh karena itu, saya mengucapkan terima kasih yang tak terhingga kepada:

1. Prof. Dr. Hj. Tati Narawati, M.Hum, sebagai Ketua Prodi Pendidikan Seni Pascasarjana Universitas Pendidikan Indonesia yang tak pernah lelah untuk memberikan stimulus dan pencerahan. Terima kasih pula atas pengantarnya mengawali buku ini.

2. Prof. Dr. Waridi, M.Hum (alm), Beliau adalah pembimbing tesis saya yang setia memberikan bimbingan disamping harus bertugas sebagai Rektor ISI Surakarta, yang sesaat setelah selesai membimbing saya Beliau dipanggil kehadirat Tuhan Yang Maha Esa. Untuk Beliau, Al-Fatihah......

3. Uus Karwati, M.Sn, Beliau adalah pembimbing tesis yang jeli dalam mengoreksi puspa ragam kesalahan dalam konten tulisan. Semoga kebaikannya mendapat balasan dari Allah S.W.T.

4. Abah Apung Supena Wiratmadja (alm), sebagai pupuhu tembang Sunda yang selalu bersemangat untuk membagi pengalamannya dalam jagat tembang Sunda.

5. Kang Rd. Gan-Gan Garmana, sebagai nara sumber utama sekaligus guru kacapi yang pengorbanannya tiada tara, karena telah banyak menyiapkan waktu, tenaga, dan pikiran khusus untuk penulis dengan tulus dan tanpa pamrih. Semoga kebaikannya mendapat balasan yang setimpal.

6. Bapak Ruk-Ruk Rukmana, sebagai nara sumber utama yang juga ikut mewariskan ilmu kacapinya dengan setulus hati.

7. Semua pihak yang tidak dapat disebutkan satu-persatu, yang telah banyak memberikan bantuan baik moril maupun materil demi terwujudnya penulisan buku ini. 
Semoga semua kebaikan yang diberikan kepada penulis mendapat balasan dari Allah S.W.T, dan diberikan kemudahan dalam segala urusan. Amien.

Sumedang, 1 Februari 2018

Penulis 


\section{Daftar Isi}

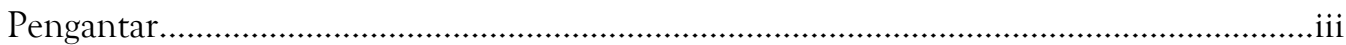

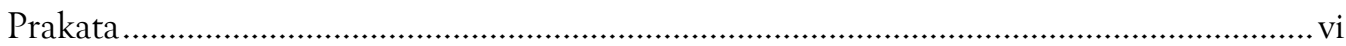

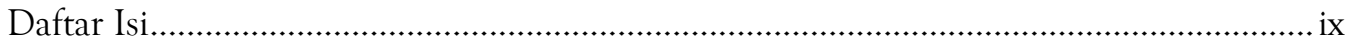

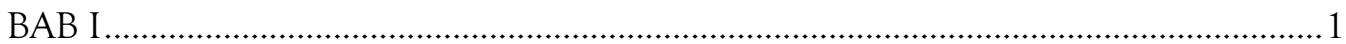

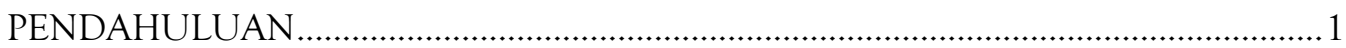

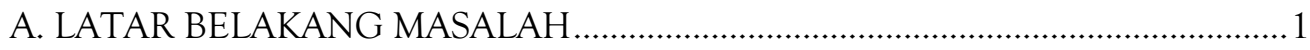

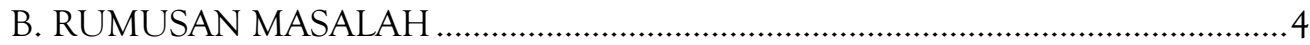

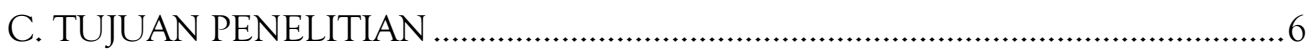

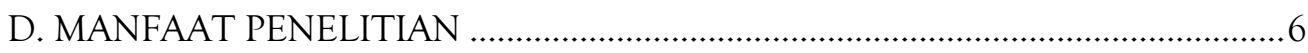

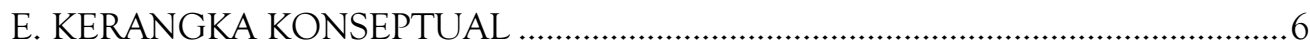

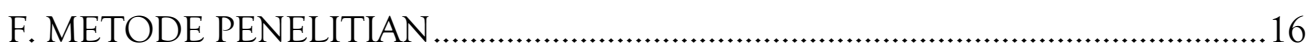

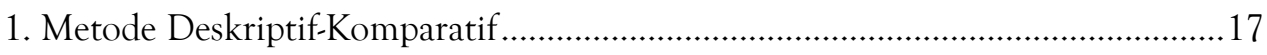

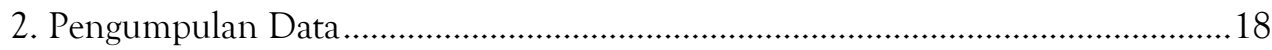

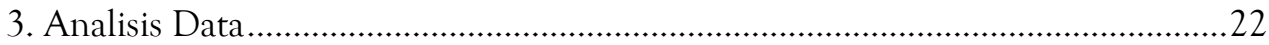

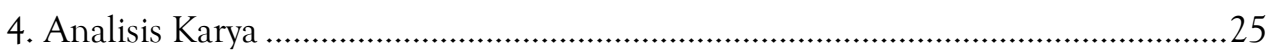

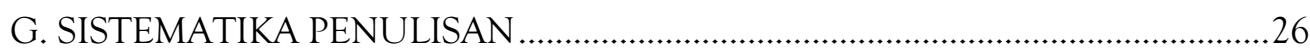

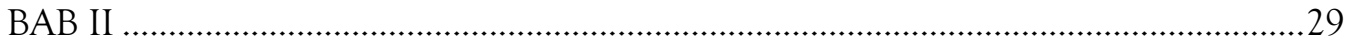

KONSEP DASAR TEMBANG SUNDA CIANJURAN …………………………........29

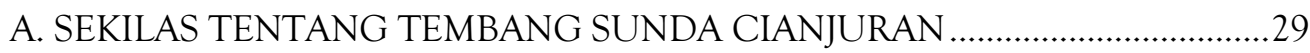

B. KOMPONEN DALAM TEMBANG SUNDA CIANJURAN ………………..........32

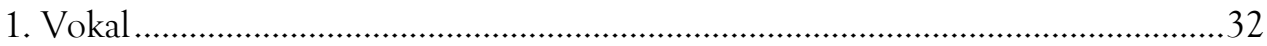

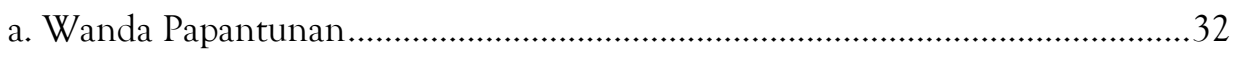

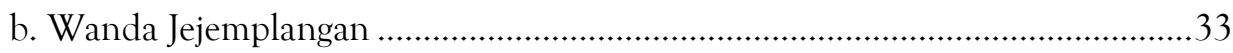

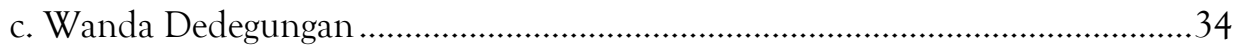

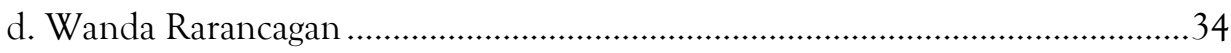

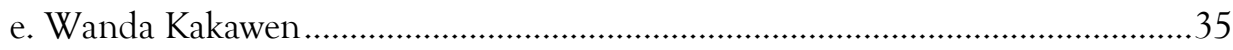

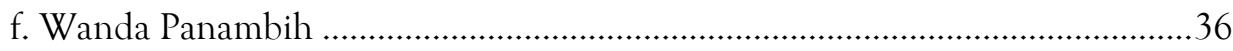

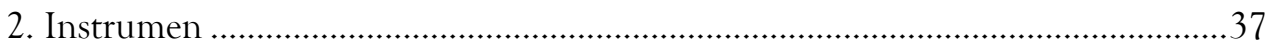

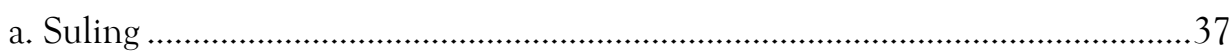

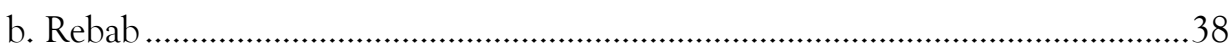




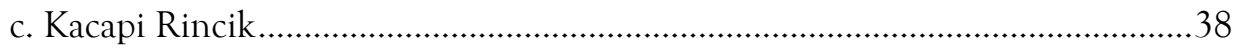

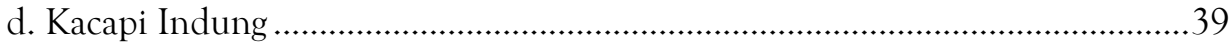

C. MUSIKALITAS DALAM TEMBANG SUNDA CIANJURAN ………………........41

1. Sentral Musik dalam Tembang Sunda Cianjuran....................................................4

2. Hubungan Komunikasi Saat Pertunjukan .............................................................46

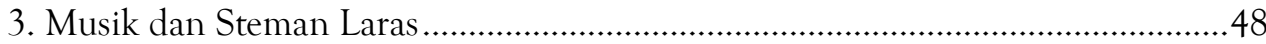

D. PIRIGAN KACAPI INDUNG DALAM TEMBANG SUNDA CIANJURAN ......51

1. Pengertian Pirigan .............................................................................................51

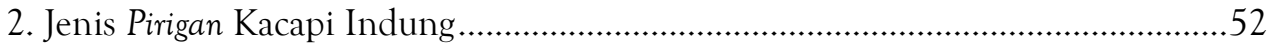

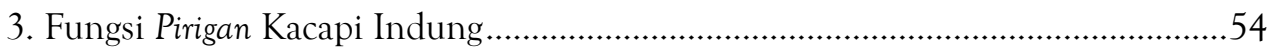

4. Bentuk dan Struktur Pirigan Kacapi Indung ..........................................................57

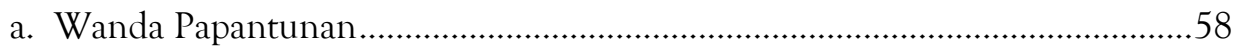

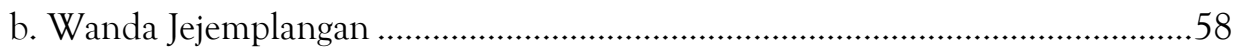

c. Wanda Dedegungan ......................................................................................59

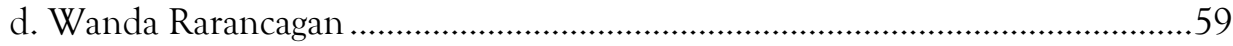

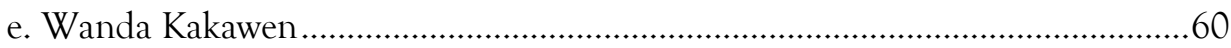

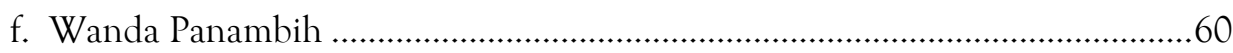

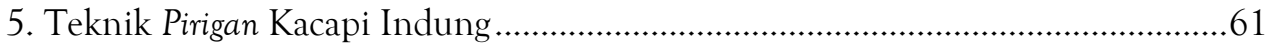

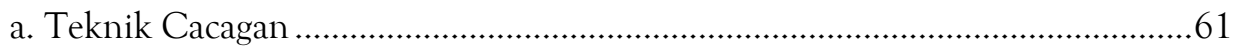

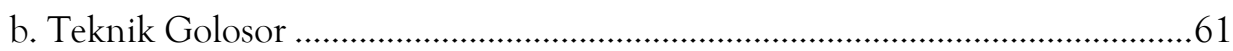

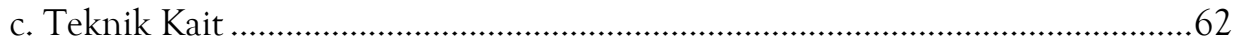

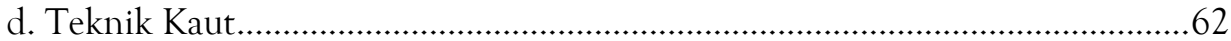

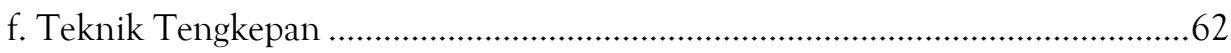

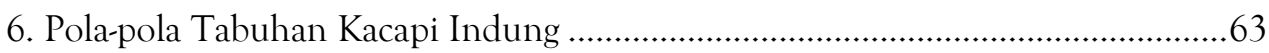

a. Tabuhan Pasieupan ………………………………….................................63

b. Tabuhan Kemprangan ...........................................................................63

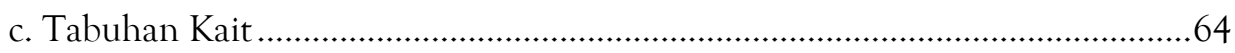

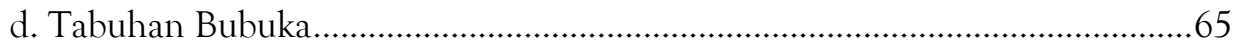

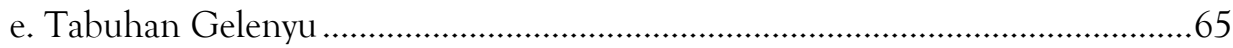

E. KREATIVITAS SENIMAN TEMBANG SUNDA CIANJURAN _........................65

F. GAYA PIRIGAN KACAPI INDUNG DALAM TEMBANG SUNDA CIANJURAN 


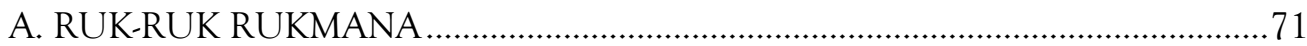

1. Latar Belakang Kehidupan Keluarga dan Lingkungan ...........................................71

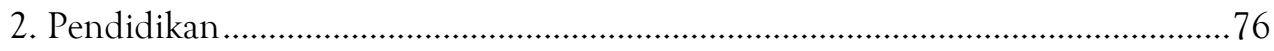

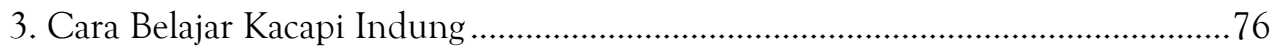

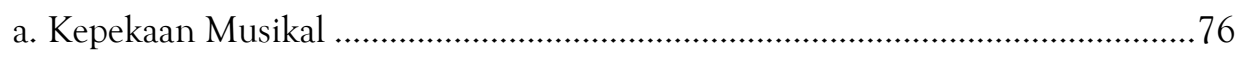

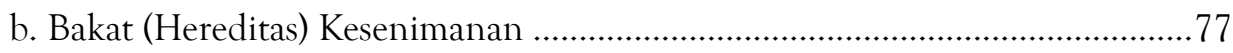

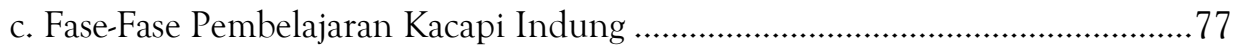

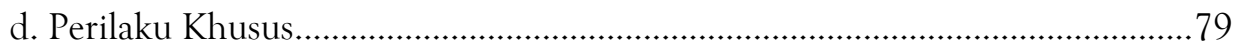

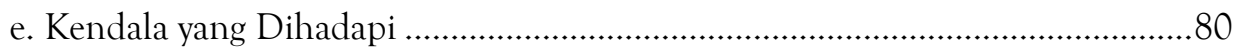

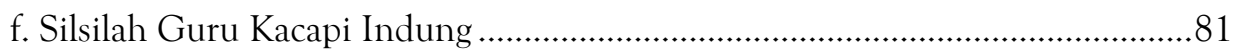

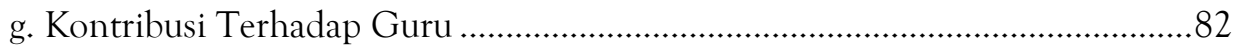

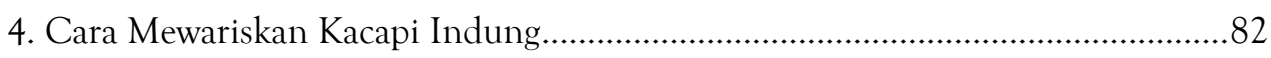

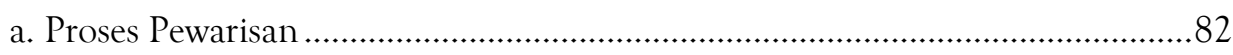

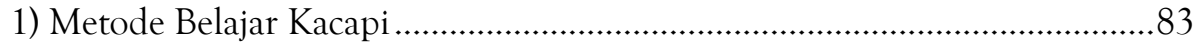

2) Pendekatan dalam Pengajaran Kacapi............................................................83

3) Tahapan Pembelajaran Kacapi ...................................................................... 83

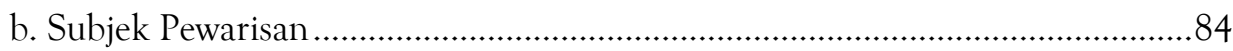

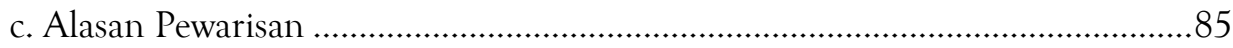

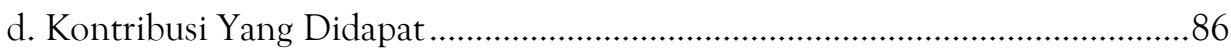

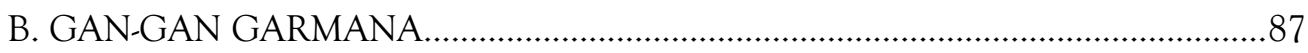

1. Latar Belakang Kehidupan Keluarga dan Lingkungan .............................................87

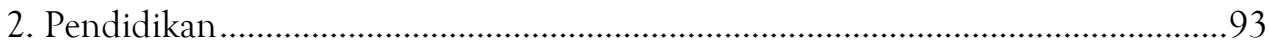

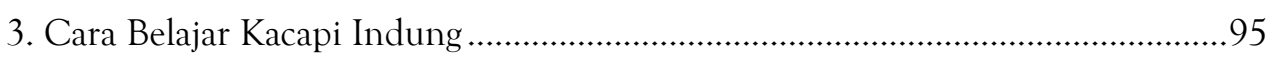

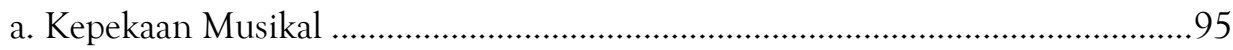

b. Bakat (Hereditas) Kesenimanan ......................................................................95

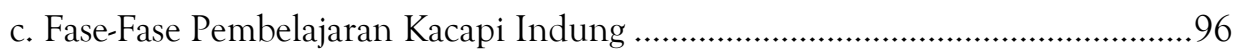

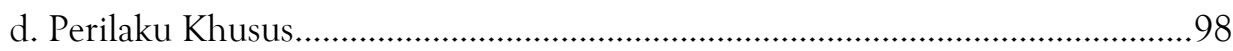

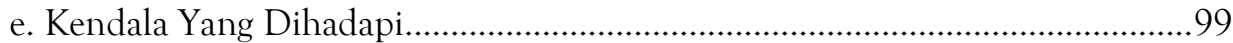

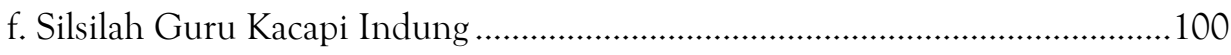

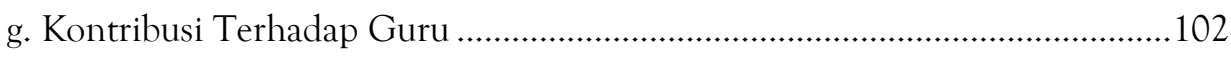




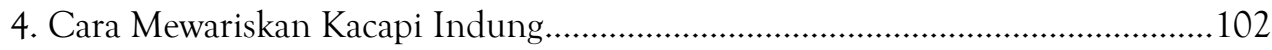

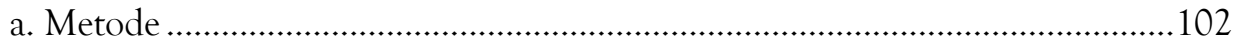

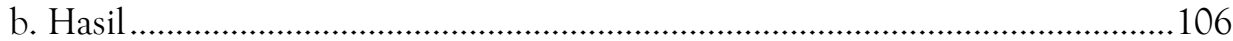

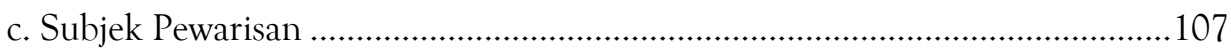

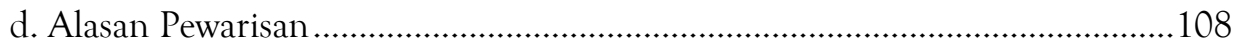

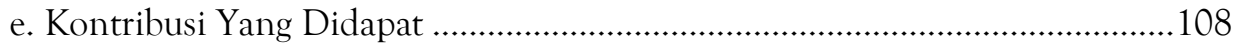

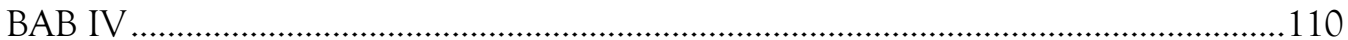

KESENIMANAN RUK-RUK RUKMANA DAN GAN-GAN GARMANA DALAM

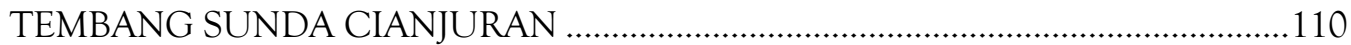

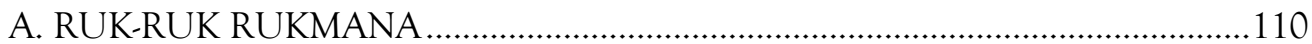

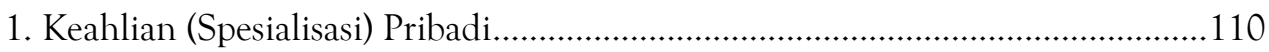

a. Penguasaan Teknik Permainan Kacapi Indung...................................................111

b. Penguasaan Pola-Pola Tabuhan Kacapi Indung .................................................113

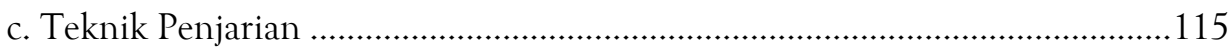

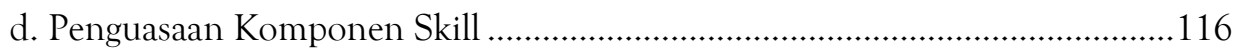

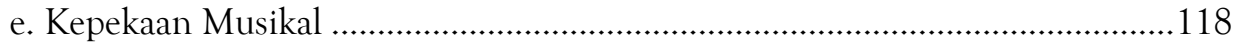

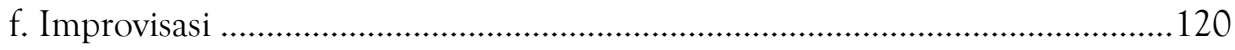

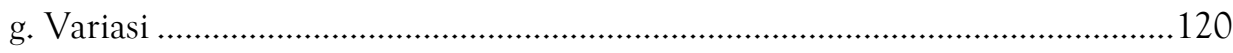

h. Cara Menyetem Kacapi Indung................................................................122

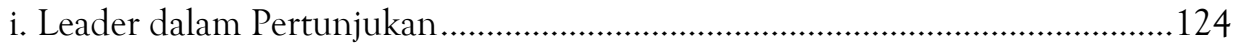

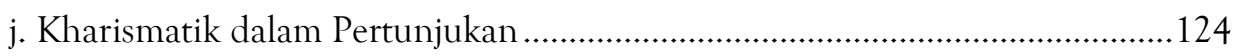

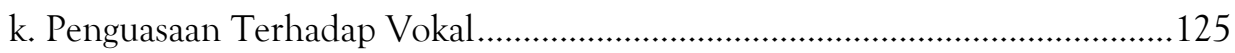

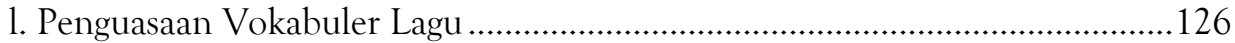

2. Kemampuan Sebagai Penyaji (Performer) ..........................................................127

3. Eksistensi dalam Tembang Sunda Cianjuran ...................................................133

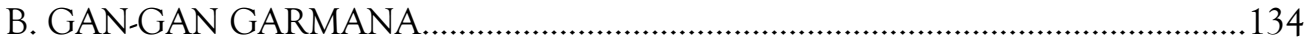

1. Keahlian (Spesialisasi) Pribadi..........................................................................134

a. Penguasaan Teknik Permainan Kacapi Indung.............................................135

b. Penguasaan Pola-Pola Permainan Kacapi Indung ...........................................136

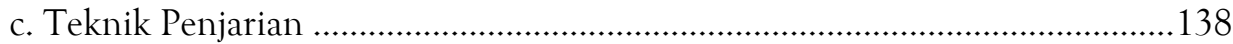

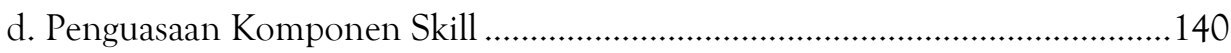

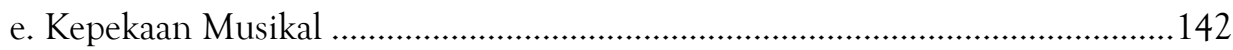

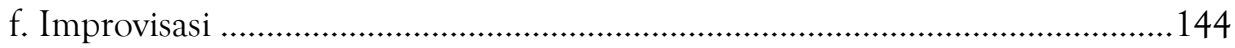




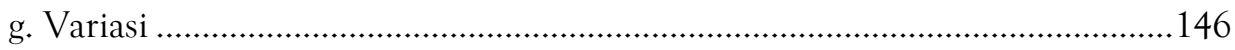

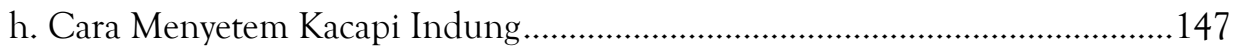

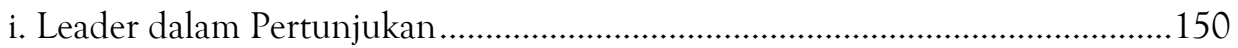

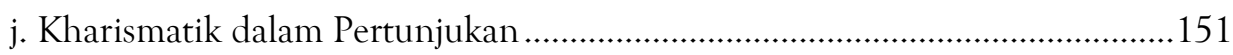

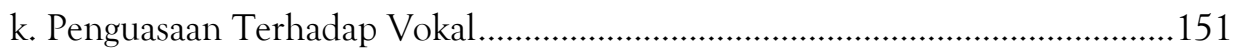

1. Penguasaan Vokabuler Lagu ..........................................................................153

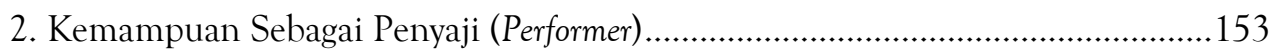

3. Eksistensi dalam Tembang Sunda Cianjuran ....................................................157

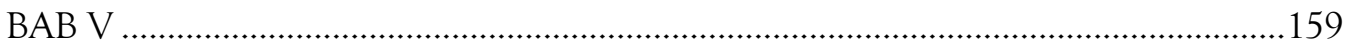

KREATIVITAS, PANDANGAN DAN PEMIKIRAN GAN-GAN GARMANA DAN RUK-RUK RUKMANA DALAM TEMBANG SUNDA CIANJURAN ........................159

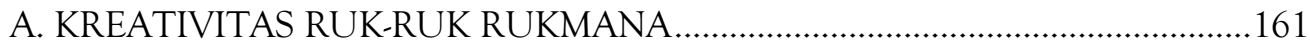

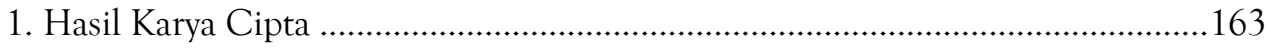

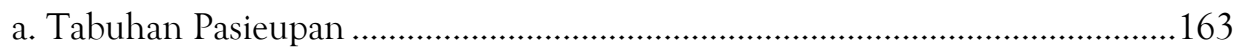

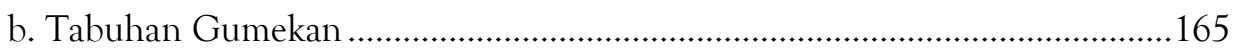

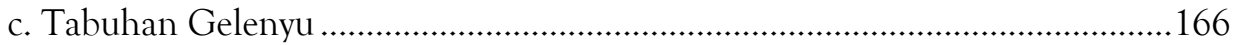

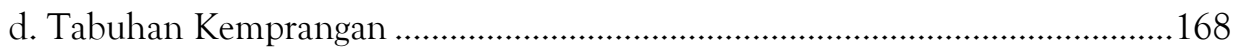

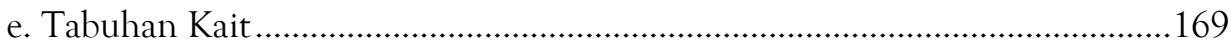

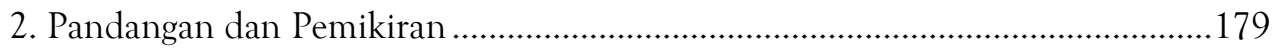

a. Sikap dan Pandangan Terhadap Kacapi Indung .............................................179

b. Pandangan Tentang Pirigan dalam Tembang Sunda Cianjuran.......................180

c. Konsep Pemikiran Tentang Pirigan Kacapi Indung ........................................180

3. Implikasi Terhadap Dunia Pendidikan ............................................................181

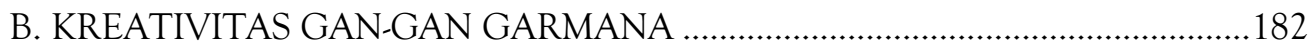

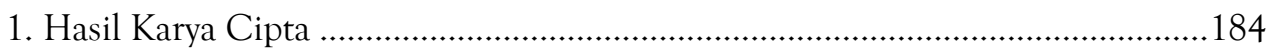

a. Tabuhan Pasieupan ................................................................................185

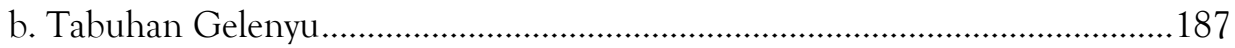

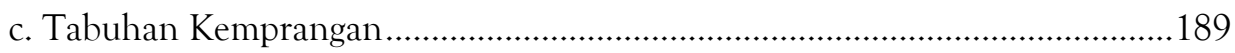

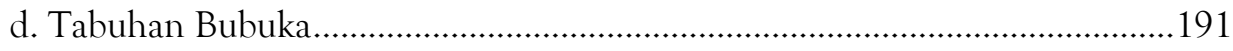

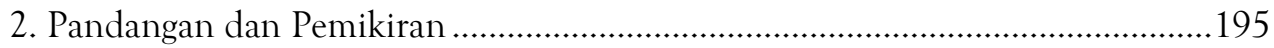

a. Sikap dan Pandangan Terhadap Kacapi Indung ..............................................195

b. Pandangan Tentang Pirigan dalam Tembang Sunda Cianjuran......................195 
c. Konsep Pemikiran Tentang Pirigan Kacapi Indung ..........................................196

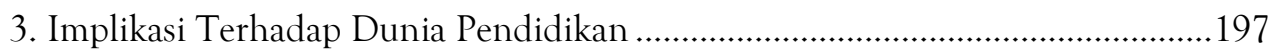

C. PERBANDINGAN HASIL ANALISIS GAYA PIRIGAN RUK-RUK RUKMANA

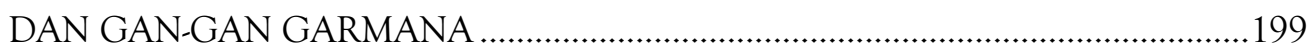

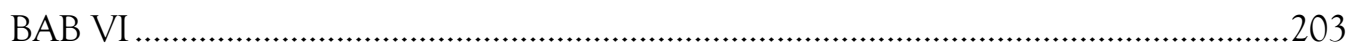

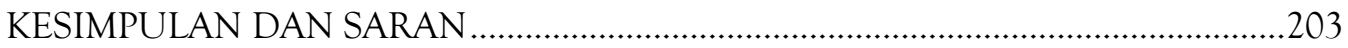

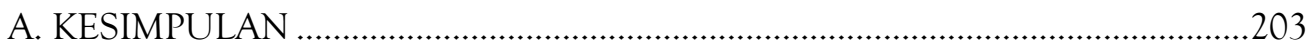

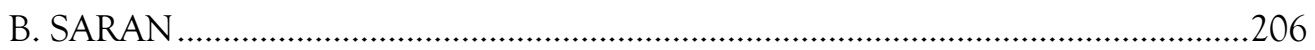

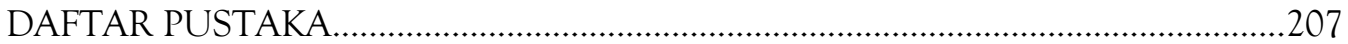

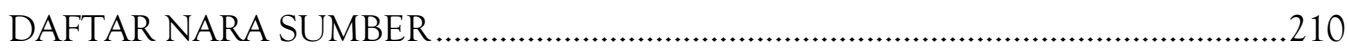

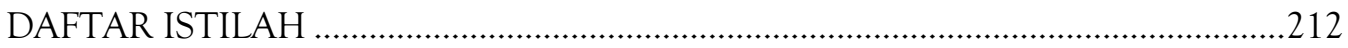

Dapatkan bacaan lengkap di:

http://books.google.com/books/about?id=ftZKDwAAQBAJ 